\title{
Electromagnetic Compatibility of Impedance Source Inverters
}

\author{
Krzysztof Bernacki ${ }^{1}$, Zbigniew Rymarski ${ }^{1}$ \\ ${ }^{1}$ Institute of Electronics, Faculty of Automatic Control, Electronics and Computer Science, \\ Silesian University of Technology, \\ Akademicka St. 16, 44-100 Gliwice, Poland \\ krzysztof.bernacki@polsl.pl
}

\begin{abstract}
In the last decade, many new structures of Impedance Source Networks have been presented and applied to a variety of powering systems. Electromagnetic Compatibility (EMC) testing is a required procedure, when introducing a new product to the market, in order to confirm that a particular device meets the required standards.

The novelty presented in this article are the results of research on the conducted disturbance and radiated emission on five selected Impedance Source Networks (ISN) structures that were performed in a certified EMC chamber along with a discussion of these results.

The description of the results will help designers to select the appropriate structure, and will help to determine the level of additional electromagnetic disturbances that can be expected by using the selected structure with respect to an inverter that does not use an impedance network structure. As yet, the research on radiated emission and conducted disturbances for Voltage Source Inverter (VSI) with ISN has neither been described nor analysed. The article concerns five Impedance Source Networks (ISN) structures.
\end{abstract}

Index Terms-Impedance source inverter; electromagnetic compatibility; conducted disturbance; radiated emission; threelevel PWM scheme; constant boost control.

\section{INTRODUCTION}

Using a Z-Source type of an Impedance Source Network (ISN) [1] to step-up the input DC voltage is a solution that has been used for the past ten years to increase the output voltage of a Voltage Source Inverter (VSI). The first basic version of a Z-Source circuit [2] had a disadvantage - a discontinuous input current. Since then, the number of new proposed ISN systems [3]-[6] is still increasing. The ZSource circuit, like most of the step-up DC/DC converters, stores energy in the inductances. These inductances always have an influence on the control transfer function of the VSI. The influence on the control transfer function determines affects the dynamic characteristics of a VSI with impedance networks [7], [8]. ISN are increasingly used in renewable

Manuscript received 6 August, 2016; accepted 19 February, 2017.

Krzysztof Bernacki was supported by Polish National Science Centre, grant no. 2015/17/N/ST7/03720: 'Dynamic properties of voltage source inverters with impedance networks, supplied from low DC voltage, taking into account the real parameters of soft magnetic materials'.

This work was partially supported by the Polish Ministry of Science and Higher Education funding for statutory activities.

The calculations were carried out using the IT infrastructure funded by GeCONiI project (POIG.02.03.01-24-099/13). energy sources such as solar panels or fuel cells, etc. [9][11].

The novelty of this work is the analysis of the five most often used ISN structures, in particular tests on radiated emission and conducted disturbance. All of the experiments produced relative measurements values, which were compared with each other. The experiments were performed in the certified EMC chamber CHC Franconia (Fig. 1(a)) using the experimental model of an inverter working with ISN. The experiments were supervised by a person who is authorized to conduct these kinds of tests. The experimental model of the inverters was designed in line with the rules of power and signal integrity, and in accordance with the norms that are currently in force [12], [13] as well as with standard engineering practice.
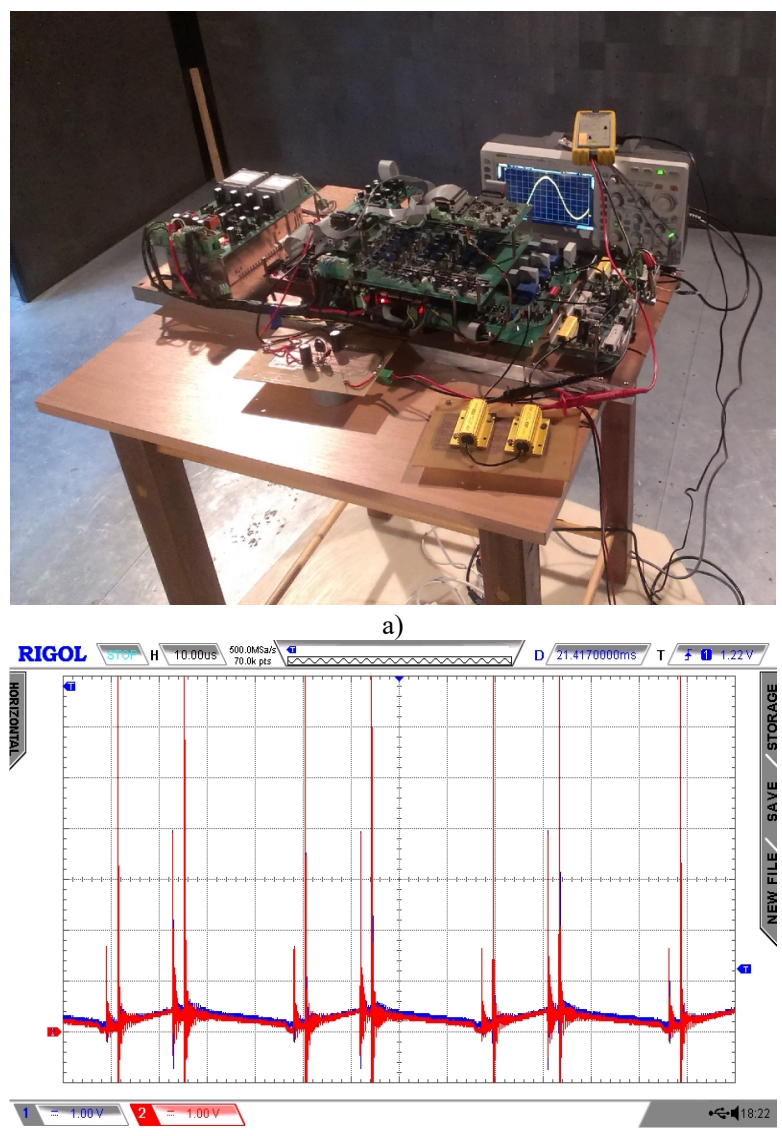

b)

Fig. 1. Experimental inverter (a) and current chokes $L 1$ in $L 2$ of the qZSI $d z=0.3, V_{O U T p p}=120 \mathrm{~V}, R_{L O A D}=47 \Omega, \mathrm{CCM}, 1 \mathrm{~A} / \mathrm{div}(\mathrm{b})$. 
A PWM modulation scheme is the control algorithm of inverter switches. The H-bridge circuit and three-level modulation is a typical solution among the single-phase voltage inverters that are dedicated for UPS systems. The authors of [14] tested three PWM modulation schemes specifying the output voltage, radiated emission and conducted disturbance for each test modulation scheme. The first schematic does not permit the zero states of the inverter to be identified, because the control of switches due to the logical product (logical conjunction) control two opposite switches in the H-bridge. The second schematic should be rejected because of the synchronization issues between the two waveforms in the two branches of the H-bridge. The implementation of the third schematic for the control of a ZSource network was presented in [7]. Additionally, the lowest levels of registered electromagnetic interference levels were obtained for the control scheme described in [14] as the third modulation scheme. The authors of [14] presented a method of a control algorithm for inverter $\mathrm{H}$ bridge switches that influenced the registered radiated emission and conducted disturbance.

Many methods of ISN control were presented in [15]. The basic method of control, which is called a Constant Boost Control, was used in this work. In this solution, the $d_{Z}$ coefficient ("shoot through" state) is constant, and therefore its influence on the results that are obtained are limited.

In all impedance networks, the energy is stored in the inductance in a "shoot through" state, which is implemented by switches in the H-bridge inverter in its zero states (when the input voltage of the output filter $L_{F} C_{F}$ is zero). One disadvantage of an impedance network is the large power losses in the "shoot through" state - an additional current impulse goes through the switches in the H-bridge inverter.

The "shoot through" state thus causes power losses that are dependent on the length of the $d_{Z}$ coefficient. These power losses cause the loss of the effectiveness of an inverter working with impedance networks - ISI. Additionally, in an inductance ISN, significant changes in the current value can be observed (Fig. 1(b)).

The authors of the structures present both the advantages and disadvantages of their solutions. They describe a solution dedicated to reduce problems with Electromagnetic Compatibility (EMC). However, in the literature, no one has performed comparative studies of several structures by defining the recorded levels of electromagnetic disturbances. Such relative comparative studies would have to determine the estimated values of the recorded levels of disturbance depending on the structures that were applied.

In this study, research related to conducted disturbances and radiated emission of five (Table I) selected structures of the impedance network was performed in a certified chamber CHC Francomia. The selected structures were:

- ZSI (Z-Source Inverter Fig. 2(a)) [1] represents symmetrical structures with a Discontinuous Input Current (DIC) with a decentralized connection to a ground,

- qZSI (quasi-Z-Source Inverter Fig. 2(b)) [16] represents asymmetrical structures with a Continuous Input Current (CIC) with a centralized connection to a ground,
- CqZSI (Cascaded quasi-Z-Source Inverter Fig. 2(c)) [17] represents asymmetrical structures that have a more complex solution than the qZSI, a structure of a cascade of a few qZSI (in our case two qZSI are connected) with a CIC with a centralized connection to a ground,

- SLZSI (Switched Inductor Z-Source Inverter Fig. 2(d)) [18] represents symmetrical structures that have a more complex solution than a ZSI with a DIC and with a decentralized connection to a ground,

- LCCT-qZSI (Inductor-Capacitor-Capacitor-Transformer quasi-Z-Source Inverter) [19] represents structures with a CIC that use a transformer with a centralized connection to a ground.

TABLE I. CHARACTERISTICS OF DIFFERENT IMPEDANCES

\begin{tabular}{|c|c|c|c|c|c|}
\hline \multicolumn{6}{|c|}{ NETWORKS. } \\
\hline & ZSI & qZSI & CqZSI & SLZSI & $\begin{array}{c}\text { LCCT- } \\
\text { qZSI }\end{array}$ \\
\hline $\begin{array}{l}\text { Boost } \\
\text { factor }\end{array}$ & $\begin{array}{c}\frac{1}{1-2 d_{Z}} \\
0 \leq d_{Z} \leq 0.5\end{array}$ & 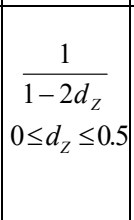 & $\begin{array}{c}\frac{1}{1-3 d_{Z}} \\
0 \leq d_{Z} \leq 1 / 3\end{array}$ & $\begin{array}{c}\frac{1+d_{z}}{1-3 d_{Z}} \\
0 \leq d_{Z} \leq 1 / 3\end{array}$ & $\begin{array}{c}\frac{1}{1-(n+1) d_{Z}} \\
0 \leq d_{Z} \leq(n+1)^{-1} \\
\mathrm{n}-\text { is } \\
\text { transformer } \\
\text { turns ratio }\end{array}$ \\
\hline Vzout & $\frac{1}{1-2 d_{z}} V_{D C}$ & $\frac{1}{1-2 d_{z}} V_{D C}$ & $\frac{1}{1-3 d_{Z}} V_{D C}$ & $\frac{1+d_{z}}{1-3 d_{z}} V_{D C}$ & $\frac{1}{1-(n+1) d_{Z}} V_{D C}$ \\
\hline $\begin{array}{l}\text { Number } \\
\text { of } \\
\text { elements }\end{array}$ & $\begin{array}{c}2 \text { inductors } \\
2 \text { capacitors } \\
1 \text { diode }\end{array}$ & \begin{tabular}{|c|}
2 \\
inductors \\
2 \\
capacitors \\
1 diode \\
\end{tabular} & $\begin{array}{c}3 \text { inductors } \\
4 \text { capacitors } \\
2 \text { diode }\end{array}$ & $\begin{array}{c}4 \text { inductors } \\
2 \text { capacitors } \\
7 \text { diode }\end{array}$ & $\begin{array}{c}1 \text { transform. } \\
1 \text { inductor } \\
2 \text { capacitors } \\
1 \text { diode }\end{array}$ \\
\hline $\begin{array}{c}\text { Common } \\
\text { ground }\end{array}$ & No & Yes & Yes & No & Yes \\
\hline $\begin{array}{c}\text { CIC } \\
\text { (Contin. } \\
\text { input } \\
\text { current) }\end{array}$ & No & Yes & Yes & No & Yes \\
\hline
\end{tabular}

One type of control Constant Boost Control [20] was used in all of the ISN structures that were studied, which has appeared to have the least impact due to both the dynamics of the inverter circuit with the ISN and the recorded radiated emission and conducted disturbance.
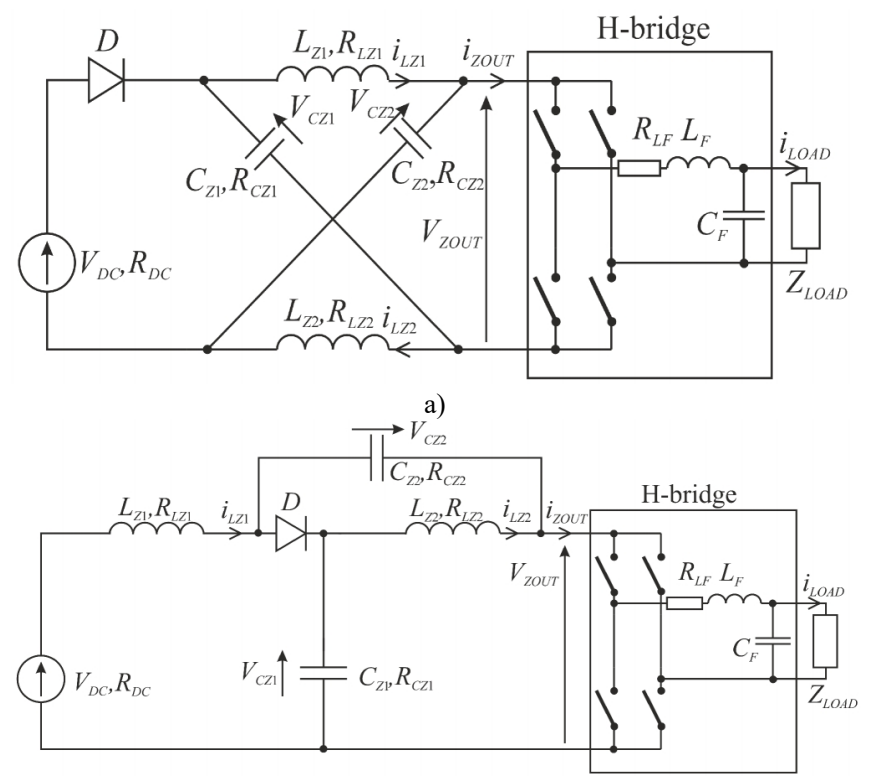

b) 


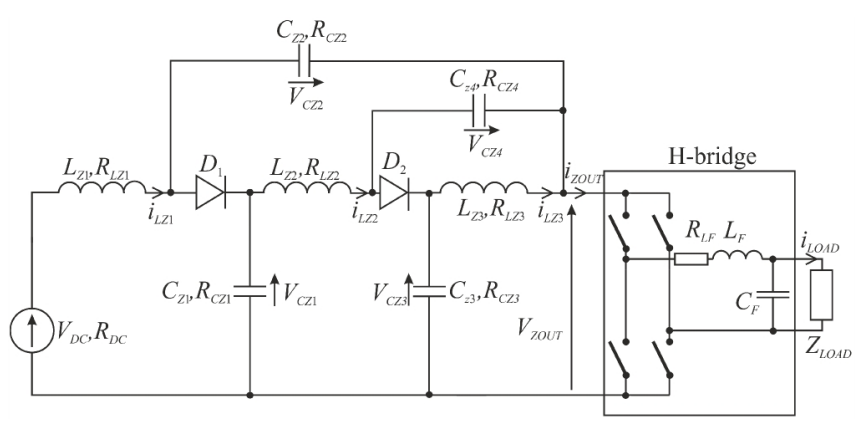

c)

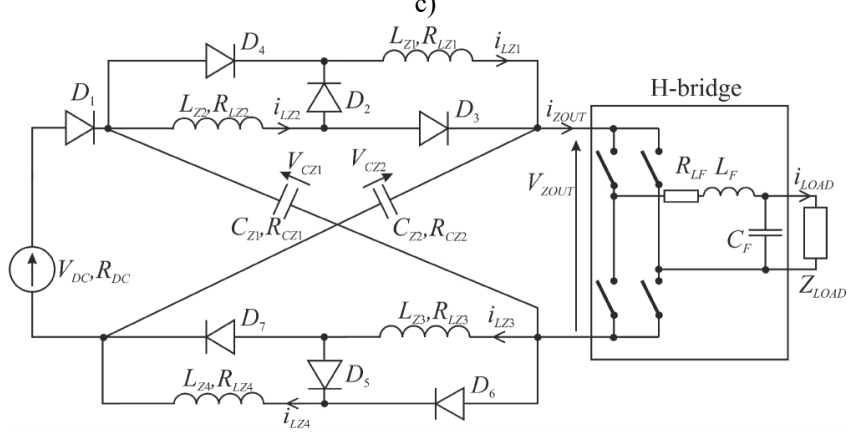

d)

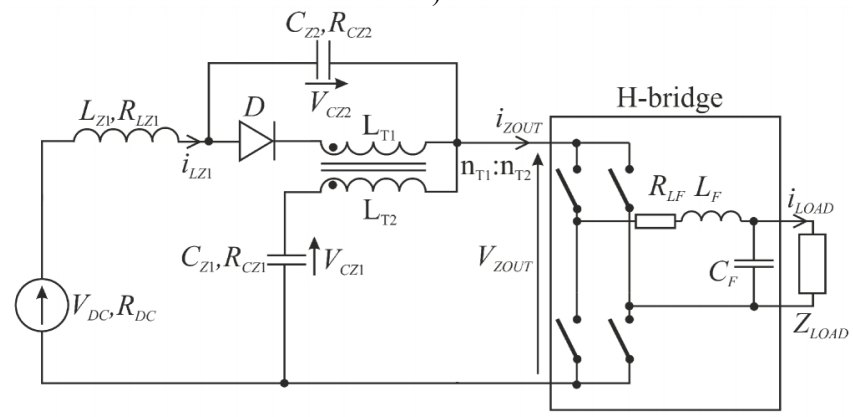

e)

Fig. 2. Analysed impedance networks: a) ZSI (Z-Source Inverter) [1], parameters of the experimental model: $L_{Z 1}=L_{Z 2}=1 \mathrm{mH}, C_{Z 1}=C_{Z 2}=100$ $\mathrm{uF}, f_{C}=25600 \mathrm{~Hz}, L_{F}=2 \mathrm{mH}, C_{F}=1 \mathrm{uF}$; b) qZSI (quasi-Z-Source Inverter) [16], parameters of the experimental model: $L_{Z 1}=L_{Z 2}=1 \mathrm{mH}$, $C_{Z 1}=C_{Z 2}=100 \mathrm{uF}, f_{C}=25600 \mathrm{~Hz}, L_{F}=2 \mathrm{mH}, C_{F}=1 \mathrm{uF}$; c) CqZSI (Cascaded quasi-Z-Source Inverter) [17], parameters of the experimental model: $L_{Z 1}=L_{Z 2}=1 \mathrm{mH}, C_{Z 1}=C_{Z 2}=100 \mathrm{uF}, f_{C}=25600 \mathrm{~Hz}, L_{F}=2$ $\mathrm{mH}, C_{F}=1 \mathrm{uF}$; d) SLZSI (Switched Inductor Z-Source Inverter) [18], parameters of the experimental model: $L_{Z 1}=L_{Z 2}=1 \mathrm{mH}, C_{Z 1}=C_{Z 2}=100$ $\mathrm{uF}, f_{C}=25600 \mathrm{~Hz}, L_{F}=2 \mathrm{mH}, C_{F}=1 \mathrm{uF}$; e) LCCT-qZSI (InductorCapacitor-Capacitor-Transformer quasi-Z-Source Inverter) [19], parameters of the experimental model: $L_{Z 1}=1 \mathrm{mH}, C_{Z 1}=C_{Z 2}=100 \mathrm{uF}, f_{C}$ $=25600 \mathrm{~Hz}, L_{F}=2 \mathrm{mH}, C_{F}=1 \mathrm{uF}$, transformer turns ratio 1:1.

In this mode, the control should be provided with the relation coefficient $d_{Z} \leq 1-M$, where $M$ is the modulation index of the sine. The "shoot through" state must be the same or shorter than the zero-state inverter. For example, the control "Maximum Boost Control" would cause a larger voltage gain [21], when the ratio $d_{Z}$ changes with the sinusoidal waveform of the reference when $d Z(\omega t)=1$ $M \sin (\omega \mathrm{t})$. It appears that such a dynamic parameter change in $d_{Z}$ may affect the register levels of the electromagnetic disturbances and consequently, the results may be inconclusive. In the ISN Super-MSSTM Sendust (MS) choke structure, an alloy-powder material of the toroid core RTMSS material was used. The influence of materials on VSI systems has been described in the literature [8], [22]. Changing the operating temperature of inverters also has a significant impact on their performance [23], [24], [25]. The values of the elements in an ISN structure (capacitance and inductance) are calculated in accordance with [7].

In this study, only the mode CCM (Continuous Current Mode) was used for each test structure. Mode DCM (Discontinuous Current Mode) may add additional electromagnetic interference.

\section{EMC THEORY}

In order to specify the impact of the ISN on the electromagnetic interference, the impact of change rate modulation depth $M$ recorded disturbances were tested and analysed in the first stage. The research studies are relative, and are aimed at presenting the differences in the received levels of electromagnetic disturbance the ISN structures with the same experimental model of the inverter and the same control software.

The basic solutions that are used to reduce electromagnetic disturbances in an ISN are a common ground, the reduction of the coefficient $d_{Z}$ (shorter "shoot through" state) through the use of cascaded structures or additionally switched inductance, the use of transformers in order to reduce the number of switching elements, the application of modern soft magnetic materials in order to reduce power losses [26], the use of a quasi-resonant softswitched [27] and other steps [28]. In the experimental model, the switching frequency of the H-bridge elements were $25600 \mathrm{~Hz}$. The project VSI was consistent with current design practices [29].

\section{EMC INVESTIGATION}

The tests were performed in a certified chamber $\mathrm{CHC}$ Franconia in accordance with EN 55022 under the supervision of a person who is authorized to conduct such research. The study was divided into two phases for which tests were performed on both the conducted disturbances and radiated emission. Because of the dependence of the control ISN from the modulation index $M$, which results from the method used to control the $\mathrm{CBC}$, in each case in this study, the impact of changes in $M$ - factor for the inverter operating without the ISN analysed in the first stage of the study. The second stage focused on the analysis of the recorded levels of the disorder experimental inverter with the ISN creating the ISI. These two stages of the analysis of conducted disturbances and radiated emission were carried out in the subsequent stages. All of the tests were carried out for two loads $47 \Omega$ and $2000 \Omega$.

The analysis, which were conducted for disturbance levels (range $150 \mathrm{kHz}$ to $30 \mathrm{MHz}$ ) and radiated emission (range from $30 \mathrm{MHz}$ to $1 \mathrm{GHz}$ ), began by determining the effect of the disturbance changes of the modulation depth $M$ without impedance network structures on the observed levels. Analysis was performed for three selected values of $M$, respectively, 0.50, 0.70 and 0.95 . For each analysed case in respect of conducted disturbances, the research for the phase and neutral connections of the experimental model with the network were performed. Examples of the results are presented in Fig. 3(a) (conducted disturbances) and Fig. 3(b) (radiation emission). The collective results are presented in Table II and Table III. 
TABLE II. SUMMARY OF THE MEASUREMENT RESULTS OBTAINED FOR THE REGISTERED MAXIMUM LOCAL VALUES OF CONDUCTED DISTURBANCES VOUTPP $=120 \mathrm{~V}$.

\begin{tabular}{|c|c|c|c|c|c|c|c|c|c|c|}
\hline & \multicolumn{5}{|c|}{$R_{L O A D}=47 \Omega$} & \multicolumn{5}{|c|}{$R_{L O A D}=2000 \Omega$} \\
\hline & \multicolumn{2}{|c|}{$\begin{array}{l}\text { Registered value of the } \\
\text { conducted disturbances } \\
0.15-30 \mathrm{MHz}[\mathrm{dB} \mu \mathrm{V}]\end{array}$} & \multicolumn{2}{|c|}{$\begin{array}{c}\text { Registered value of the } \\
\text { conducted disturbances } \\
1 \mathrm{MHz}-30 \mathrm{MHz} \\
{[\mathrm{dB} \mu \mathrm{V}]}\end{array}$} & \multirow{2}{*}{$\begin{array}{c}\text { Average } \\
\text { registered } \\
\text { value } \\
0.15-30 \\
\mathrm{MHz} \\
{[\mathrm{dB} \mu \mathrm{V}]}\end{array}$} & \multicolumn{2}{|c|}{$\begin{array}{l}\text { Registered value of the } \\
\text { conducted disturbances } \\
0.15-30 \mathrm{MHz}[\mathrm{dB} \mu \mathrm{V}]\end{array}$} & \multicolumn{2}{|c|}{$\begin{array}{l}\text { Registered value of the } \\
\text { conducted disturbances } \\
1 \mathrm{MHz}-30 \mathrm{MHz}[\mathrm{dB} \mu \mathrm{V}]\end{array}$} & \multirow{2}{*}{$\begin{array}{c}\text { Average } \\
\text { registered } \\
\text { value } \\
0.15-30 \\
\mathrm{MHz} \\
{[\mathrm{dB} \mu \mathrm{V}]}\end{array}$} \\
\hline & $\begin{array}{c}\text { Average } \\
\text { registered* }\end{array}$ & $\begin{array}{c}\text { Maximum } \\
\text { registered** }\end{array}$ & $\begin{array}{c}\text { Average } \\
\text { registered* }\end{array}$ & $\begin{array}{l}\text { Maximum } \\
\text { registered } \\
* *\end{array}$ & & $\begin{array}{c}\text { Average } \\
\text { registered* }\end{array}$ & $\begin{array}{c}\text { Maximum } \\
\text { registered** }\end{array}$ & $\begin{array}{c}\text { Average } \\
\text { registered* }\end{array}$ & $\begin{array}{l}\text { Maximum } \\
\text { registered** }\end{array}$ & \\
\hline ZSI & 86.21 & 88.11 & 87.87 & 104.39 & 87.30 & 85.98 & 87.82 & 84.95 & 100.51 & 85.32 \\
\hline qZSI & 78.08 & 78.66 & 82.78 & 101.83 & 81.15 & 79.53 & 81.28 & 79.59 & 95.42 & 79.57 \\
\hline SLZSI & 85.26 & 87.39 & 86.94 & 100.14 & 86.36 & 85.43 & 86.71 & 82.88 & 96.92 & 83.76 \\
\hline CqZSI & 78.10 & 79.07 & 82.32 & 106.50 & 80.86 & 78.37 & 79.20 & 83.01 & 102.13 & 81.40 \\
\hline LCCTqZSI & 77.89 & 88.47 & 82.00 & 105.22 & 81.40 & 80.58 & 82.80 & 82.05 & 103.52 & 81.56 \\
\hline $\begin{array}{c}\text { VSI } \\
M=0.95\end{array}$ & 66.34 & 67.26 & 69.75 & 76.19 & 68.46 & 65.15 & 66.36 & 69.31 & 75.39 & 67.74 \\
\hline
\end{tabular}

Note: * Average registered value in the entire range, ** The maximum registered value in the entire range.

TABLE III. SUMMARY OF THE MEASUREMENT RESULTS OF THE CONDUCTED DISTURBANCES USING THE PEAK VALUES DETECTOR (PRESCAN), CONSTANT STEP $4 \mathrm{KHZ}, V_{\text {OUTPP }}=120 \mathrm{~V}$.

\begin{tabular}{|c|c|c|c|c|c|c|}
\hline & \multicolumn{3}{|c|}{$R_{L O A D}=47 \Omega$} & \multicolumn{3}{|c|}{$R_{L O A D}=2000 \Omega$} \\
\hline & $\begin{array}{c}\text { The average value } \\
\text { registered } \\
0.15-30 \mathrm{MHz} \\
{[\mathrm{dB} \mu \mathrm{V}]}\end{array}$ & $\begin{array}{c}\text { The average value } \\
\text { registered } \\
0.15-1 \mathrm{MHz} \\
{[\mathrm{dB} \mu \mathrm{V}]}\end{array}$ & $\begin{array}{c}\text { The average value } \\
\text { registered } \\
1-30 \mathrm{MHz} \\
{[\mathrm{dB} \mu \mathrm{V}]}\end{array}$ & $\begin{array}{c}\text { The average value } \\
\text { registered } \\
0.15-30 \mathrm{MHz} \\
{[\mathrm{dB} \mu \mathrm{V}]}\end{array}$ & $\begin{array}{c}\text { The average value } \\
\text { registered } \\
0.15-1 \mathrm{MHz} \\
{[\mathrm{dB} \mu \mathrm{V}]}\end{array}$ & $\begin{array}{c}\text { The average value } \\
\text { registered } \\
1-30 \mathrm{MHz} \\
{[\mathrm{dB} \mu \mathrm{V}]}\end{array}$ \\
\hline ZSI & 71.28 & 77.43 & 71.09 & 67.71 & 78.44 & 67.39 \\
\hline qZSI & 70.60 & 69.14 & 70.65 & 66.95 & 70.40 & 66.85 \\
\hline SLZSI & 73.93 & 76.96 & 73.86 & 68.35 & 76.65 & 68.10 \\
\hline CqZSI & 66.65 & 69.33 & 66.57 & 63.95 & 68.97 & 63.80 \\
\hline LCCTqZSI & 63.54 & 70.78 & 63.32 & 66.35 & 71.78 & 66.19 \\
\hline $\begin{array}{c}\text { VSI } \\
M=0.95\end{array}$ & 54.18 & 58.68 & 54.05 & 54.36 & 59.20 & 54.22 \\
\hline
\end{tabular}

TABLE IV. SUMMARY OF THE OBTAINED RESULTS OF THE MEASUREMENTS RADIATED EMISSION, CONSTANT STEP 40 KHZ, VoUTPP =

\begin{tabular}{|c|c|c|c|c|c|c|c|c|}
\hline & \multicolumn{4}{|c|}{$R_{L O A D}=47 \Omega$} & \multicolumn{3}{|c|}{$R_{L O A D}=2000 \Omega$} & \multirow[b]{2}{*}{$\begin{array}{c}\text { The } \\
\text { maximum } \\
\text { value } \\
\text { registered } \\
0.03-1 \\
\mathrm{GHZ} \\
{[\mathrm{dB} \mu \mathrm{V} / \mathrm{m}]}\end{array}$} \\
\hline & $\begin{array}{c}\text { The average } \\
\text { value } \\
\text { registered } \\
0.03-1 \\
\mathrm{GHZ} \\
{[\mathrm{dB} \mu \mathrm{V} / \mathrm{m}]}\end{array}$ & $\begin{array}{c}\text { The average } \\
\text { value } \\
\text { registered } \\
0.03-0.2 \\
\mathrm{GHZ} \\
{[\mathrm{dB} \mu \mathrm{V} / \mathrm{m}]}\end{array}$ & $\begin{array}{c}\text { The average } \\
\text { value } \\
\text { registered } \\
0.2-1 \mathrm{GHZ} \\
{[\mathrm{dB} \mu \mathrm{V} / \mathrm{m}]}\end{array}$ & $\begin{array}{c}\text { The } \\
\text { maximum } \\
\text { value } \\
\text { registered } \\
0.03-1 \\
\mathrm{GHZ} \\
{[\mathrm{dB} \mu \mathrm{V} / \mathrm{m}]}\end{array}$ & $\begin{array}{c}\text { The average } \\
\text { value } \\
\text { registered } \\
0.03-1 \\
\mathrm{GHZ} \\
{[\mathrm{dB} \mu \mathrm{V} / \mathrm{m}]}\end{array}$ & $\begin{array}{c}\text { The average } \\
\text { value } \\
\text { registered } \\
0.03-0.2 \\
\mathrm{GHZ} \\
{[\mathrm{dB} \mu \mathrm{V} / \mathrm{m}]}\end{array}$ & $\begin{array}{c}\text { The average } \\
\text { value } \\
\text { registered } \\
0.2-1 \mathrm{GHZ} \\
{[\mathrm{dB} \mu \mathrm{V} / \mathrm{m}]}\end{array}$ & \\
\hline qZSI & 24.83 & 44.18 & 20.72 & 70.54 & 24.16 & 42.27 & 20.30 & 68.81 \\
\hline SLZSI & 33.32 & 57.36 & 28.21 & 87.79 & 25.24 & 46.52 & 20.72 & 79.47 \\
\hline CqZSI & 27.52 & 49.47 & 22.85 & 70.54 & 23.90 & 41.49 & 20.16 & 67.05 \\
\hline LCCTqZSI & 25.35 & 43.91 & 24.38 & 67.79 & 24.26 & 42.20 & 20.16 & 65.44 \\
\hline $\begin{array}{c}\text { VSI } \\
M=0.95\end{array}$ & 20.72 & 24.90 & 19.83 & 45.82 & 20.68 & 24.71 & 19.83 & 45.85 \\
\hline
\end{tabular}

Measurements were taken at a distance of three meters from the experimental model. The first part of the measurement focused on selecting three antenna heights in the range from $100 \mathrm{~cm}$ to $200 \mathrm{~cm}$, in order to be able to select the worst case (highest recorded disorders) and the amount was included in further studies. After a preliminary analysis of the results, three heights $(100 \mathrm{~cm}, 120 \mathrm{~cm}$ and $140 \mathrm{~cm}$ ) were selected at which further measurements were carried out taking into account the amount for each of two polarizations (horizontal and vertical) and eight different settings of the test model (rotation of 45 degrees). With these guidelines, measurements were conducted in which the following features were subject to change: three heights, two polarizations, eight different settings model, three analysed values the modulation depth $M$ and two different loads $47 \Omega$ and $2000 \Omega$.

In the studies related to the conducted disturbances for each of the analysed case studies for the phase and neutral connections, experimental models of the network were used. These guidelines were used in all of the subsequent studies. The relative study for the inverter model without ISN structures showed that the impact of changes in the value of the parameter $M$ on the levels of electromagnetic disturbances is insignificant. It should be emphasized that the only aim of the relative studies was to compare the change in the value received from the analysis of the levels of electromagnetic disturbances in identical conditions (certified chamber). During the analysis, neither an additional filter nor the cover were taken into account, which would have the effect of reducing the level of interference received, and which are used in engineering practice. The use of such filters would have an additional impact on the characteristics of electromagnetic interference that were obtained, thus making the interpretation of the results difficult. 


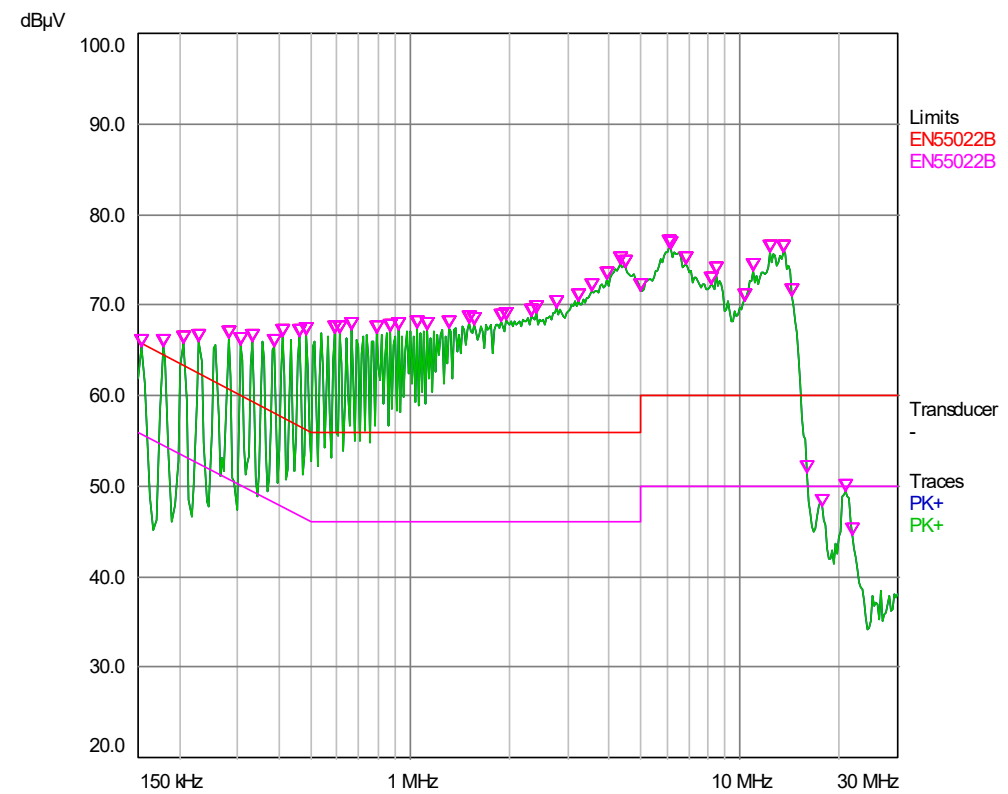

a)

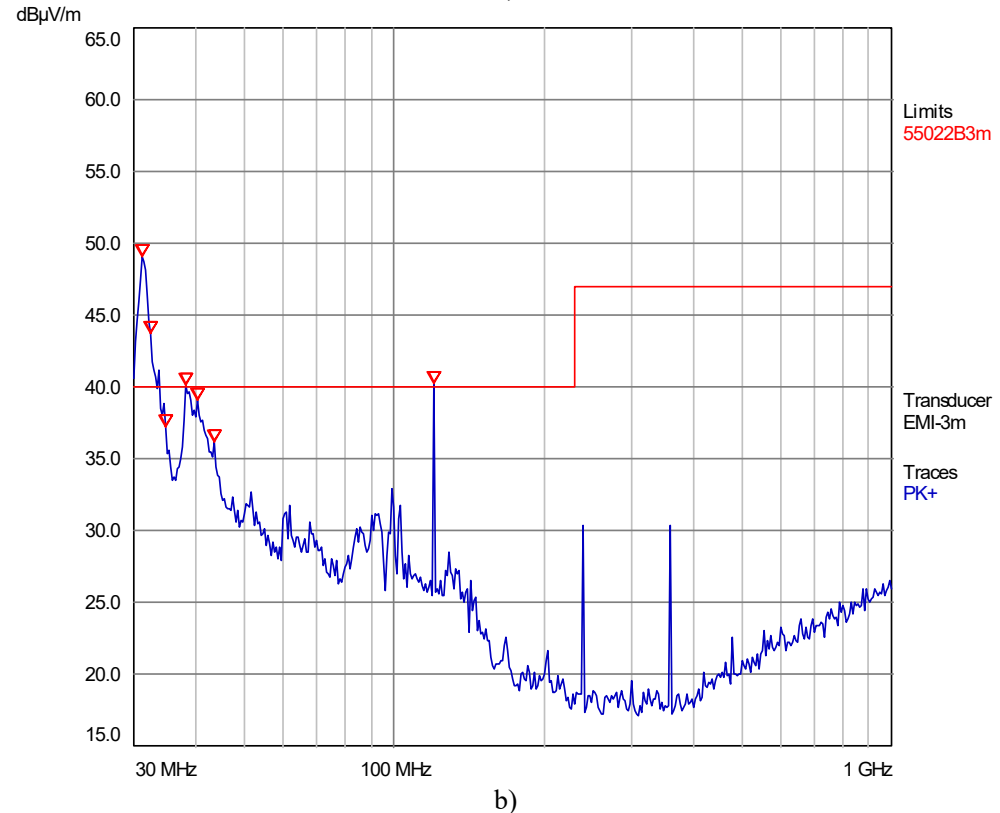

Fig. 3. Examples of the results obtained for conducted disturbances: VSI, $M=0.95, R_{L O A D}=47 \Omega, V_{D C}=62.4 \mathrm{~V}, I S R=0.65 \mathrm{~A}$ (a) and radiated, VSI, $M=$ $0.95, R_{L O A D}=47 \Omega, V_{D C}=62.4 \mathrm{~V}, I_{S R}=0.65 \mathrm{~A}$, (b) VSI (without ISN). Relative error smaller than $3 \mathrm{~dB}$.

\section{A. Conducted Disturbance}

First, a PreScan measurement using the peak detector (green - in Fig. 3(a)) was performed. The measurement was performed for the entire tested range with a constant step of $4 \mathrm{kHz}$. In second stage of the study, measurements with the detector quasi-peaks, which are marked as purple triangles were performed. The points that are marked with triangles are the places at which the standards were exceeded or where the course was in close proximity to the limit of the standards. For these locations, an additional measurement was performed in order to determine the precise maximum disturbance at the point of the local extreme. A summary of the results is presented in Table II.

Research studies are comparative, relative ones. The standards do not specify the recommended methods of the comparative characteristics that are derived from the research. For commercial work, only a test result is defined, which indicates the operation of the test system according to the standard or as dedicated with reservations, which must therefore be used to redesign the system. The method used to compare the results is based on the average of the results for an entire range, as well as the division into compartments (Table III) and analysis of the recorded average local maximum values (Table II).

When analysing the results that are obtained, one should pay attention to the characteristics of the division due to the smaller and greater variability in the values that are obtained. For the qZSI, SLZSI and CqZSI structures, a greater volatility of recorded results was observed from the frequency of $2 \mathrm{MHz}$, while for the ZSI $1.5 \mathrm{MHz}$, and for LCCTqZSI it was $800 \mathrm{kHz}$. The selection of the interval is crucial to emphasize the impact. Inclusion of too many points to wrong interval reduced impact at the calculating the average (Table III and Table IV). For the analysis of the assumed range for all of the structures from $150 \mathrm{kHz}$ to $1 \mathrm{MHz}$ - those with a lower volatility, while those in the range from $1 \mathrm{MHz}$ to $30 \mathrm{MHz}$ are considered to be in the 
range that has a greater volatility.

\section{B. Radiated Emission}

In the study of the radiated emission, preliminary analysis (uses PreScan) peak value detector was first was carried out, and then in the second step, measurements of the detector quasi-peak and detection of the average values. The analysis of the radiated emission ISN structures were carried out in the range of from $30 \mathrm{MHz}$ to $1 \mathrm{GHz}$. Being aware of the fact that the studies were designed to be comparative studies and the standards do not clearly specify the methods for comparing the characteristics that are obtained from studies conducted in these chambers, some simplification was used. Unlike the analysis conducted on the disturbances, the decision was made not to analyse the average values of the maximums of the waveforms. This was because, among other things, there was a similar trend in the waveforms of the radiated emission that was registered for the analysed structures.

The measuring step is used equal to $40 \mathrm{kHz}$ - higher value compared with conducted disturbance due to the fact analysed wider range. For the assessment of the radiated emission obtained, the average value of the results of the full range and divided into two ranges were analysed.

The entire range was split into two zones for the analysis, which - as in the case of the conducted disturbances - were divided into compartments that had the characteristics of the higher and lower volatility levels that were recorded for the radiated emission. Table IV summarizes the mean values that were obtained for the entire range and then divided into two sub-ranges, respectively, from $30 \mathrm{MHz}$ to $200 \mathrm{MHz}$ and from $200 \mathrm{MHz}$ to $1 \mathrm{GHz}$ for two $R_{L O A D}$. It also presents the maximum value that was recorded for the entire analysed range.

\section{RESULTS}

\section{A. Conducted Disturbance}

The highest average levels of conducted disturbances were obtained for the SLZSI and the ZSI structures. The highest average value recorded for the local maxima was determined for the ZSI structure. The lowest recorded levels of conducted disturbances were observed for the CqZSI and LCCTqZSI structures. The reduced levels of disorder that were observed in the other ISI systems were analysed based on a centralized reference plane and operated at a constant input current (CIC) (proposed in qZSI) as well as in CqZSI and LCCTqZSI. As regards the differences between the ZSI and SLZSI, the other structures, as described [18], should be characterized by lower levels of electromagnetic disturbances due to the lower value of the coefficient $d_{Z}$, but studies did not confirm this. Considering only the received average values (Table III), we observed higher recorded levels of disturbances for SLZSI. This result may due to the fact that a structure seven diodes were used to switch the inductance, which affects the inductance in the structure. This fact can also be confirmed by analysing the CqZSI structure simultaneously with the SLZSI structure. The structure during the test used the same value of $d_{Z}=0.27$. Despite this fact, a significant difference can be observed in the conducted disturbance in favour of the CqZSI structure (Table II and Table III). This may suggest that there is no justification for using switching elements in the ISN structure (for example with attaching coils) due to the reduction of conducted disturbances. During the selection of an ISN, it should be known that systems without switching inductance are characterized by lower levels of disturbance. The results of the comparison of the ZSI with qZSI using the analysis of the same value $d_{Z}=0.40$, present the potential to reduce conducted disturbances during when using a centralized ground and working with continuous input current (CIC). Comparison of the ZSI and qZSI in terms of conducted disturbances discredits a solution with decentralized point of reference. To compare the qZSI and CqZSI structures where the structure is a triple cascade CqZSI and to obtain output voltage level $V_{\text {OUTp }}=120 \mathrm{~V}$, the "shoot-through" for CqZSI is $d_{Z}=0.27$, and for qZSI it is the same output voltage, but with $d_{Z}=0.40$ being applied. It seems that such a significant difference in the parameter $d_{Z}$ should be reflected in the conducted disturbances results that are obtained. However, the difference for the benefit of CqZSI was only observed at negligible levels in terms of the average maximum value disorders. Taking into account the results from the average results of the entire range frequency, note the difference of a few $\mathrm{dB} \mu \mathrm{V}$. It can be concluded that the reduction factor $d_{Z}$ reduces the average value of the recorded conducted disturbances, and that the maximum values are registered at similar levels. It is clear that the lower value of the load of the recorded disorders caused lower mean values for the entire range, but it should be noted that the load at $2000 \Omega$ will operate with a DCM (Discontinuous Current Mode), which might cause additional disturbances in the current flow as presented Fig. 4 (marked with points 1 and 2).

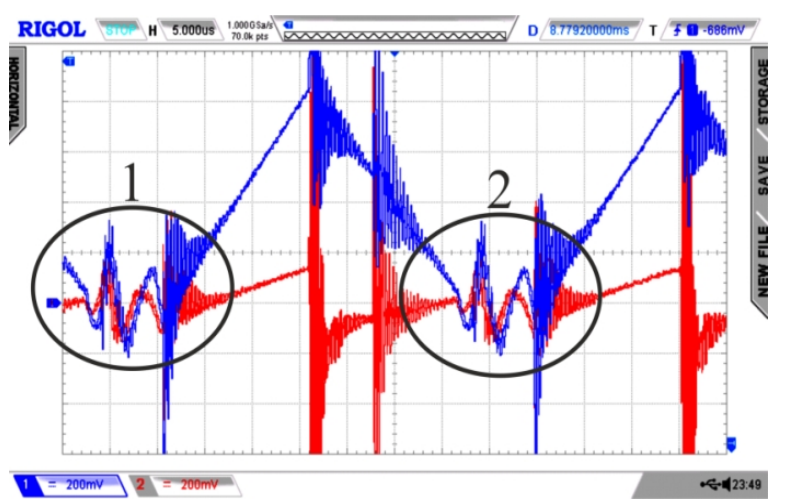

Fig. 4. Current waveforms in the chokes $L 1$ and $L 2$ in the qZSI, Discontinuous Current Mode (DCM), VOUTpp $=120 \mathrm{~V}, R_{L O A D}=2000 \Omega$, 2A / div.

Most probably, due to that fact, the LCCTqZSI structure observed higher levels recorded conducted disturbances for the load at $2000 \Omega$ than $47 \Omega$.

\section{B. Radiated Emission}

Table IV summarizes the mean values that were obtained for the entire range and divided into two sub-ranges, respectively, from $30 \mathrm{MHz}$ to $200 \mathrm{MHz}$ and from $200 \mathrm{MHz}$ to $1 \mathrm{GHz}$ for two $R_{L O A D}$. The values that were obtained for the two proposed load $R_{L O A D}$ also coincided. Analysing the results of the Table III for inverters without ISN (Voltage 
Source Inverters) the same time, it can be seen that the load change had a negligible impact on the levels of disturbances radiated and conducted. The results clearly discredited the SLZSI structures. SLZSI recorded the highest levels of radiated for the two analysed $R_{L O A D}$. It also had the highest level of the average for the entire range and the highest recorded average value for the two designated sub-ranges among the tested structures. The lowest recorded maximum levels of radiated emissions was obtained for the LCCTqZSI structure. The recorded average levels for LCCTqZSI structures were similar to the average recorded minimum values. No significant differences in the levels of interference between structures ZSI and qZSI structures were registered, as was the case during the analysis of the conducted disturbances. This may be due to the fact that the switching frequency was $25600 \mathrm{~Hz}$, which is significantly below the early registration radiated $(30 \mathrm{MHz})$. Due to this fact, a larger impact was recorded for lower frequencies (conducted disturbances). The recorded mean levels for the
CqZSI structure can be defined as acceptable in comparison with the levels obtained for the SLZSI structure, which used the same value of $d_{Z}$ ("shoot through" state).

\section{CONCLUSIONS}

Research on conducted disturbances (Fig. 5(a)-Fig. 5(e) in Appendix A) and radiated emission (Fig. 5(f)-Fig. 5(j) in Appendix A) help to demonstrate and confirm some important issues concerning the Electromagnetic Compatibility of Impedance Source Inverters. The importance of using a centralized system to connect to the reference plane was shown. This research also helped to prove that the level of conducted disturbances depends mainly on the continuous input current. In addition, it confirmed the validity of the reduction coefficient $d_{Z}$ to reduce electromagnetic disturbances. Keep in mind that the reduction parameter $d_{Z}$ is linked to an increase in the value of the currents, which accumulate more power choke structures in less time.

\section{APPENDIX A}

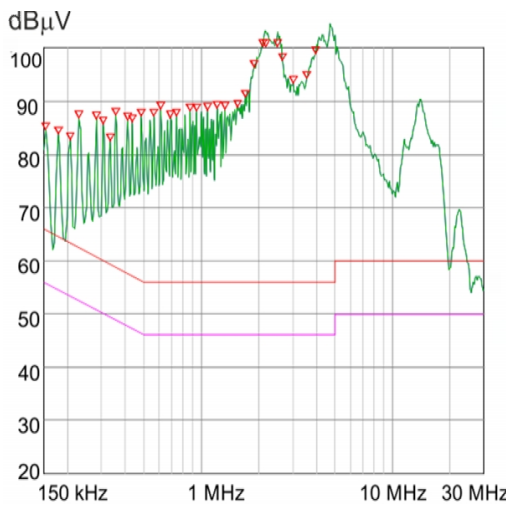

a)

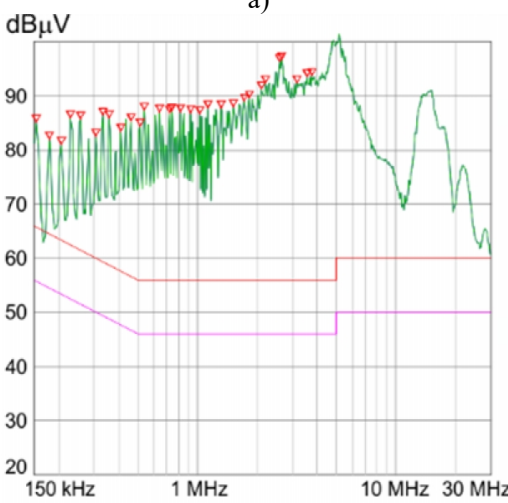

c)

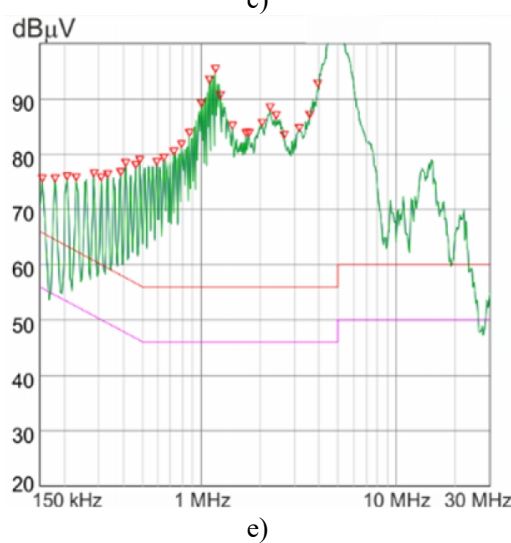

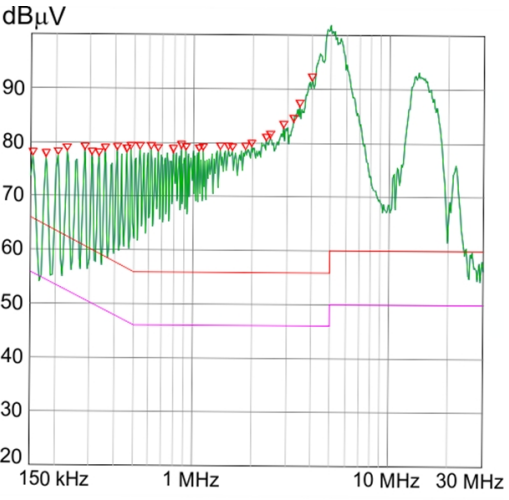

b)

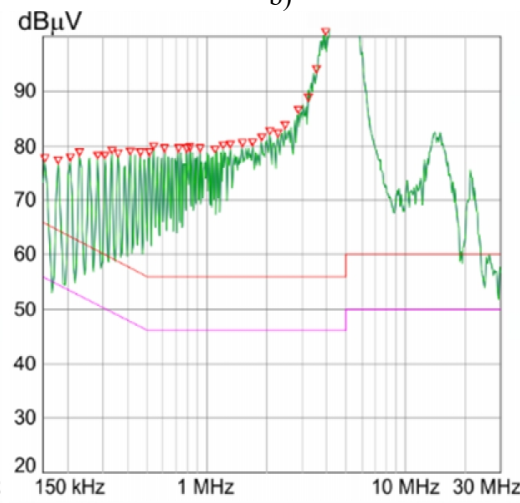

d)

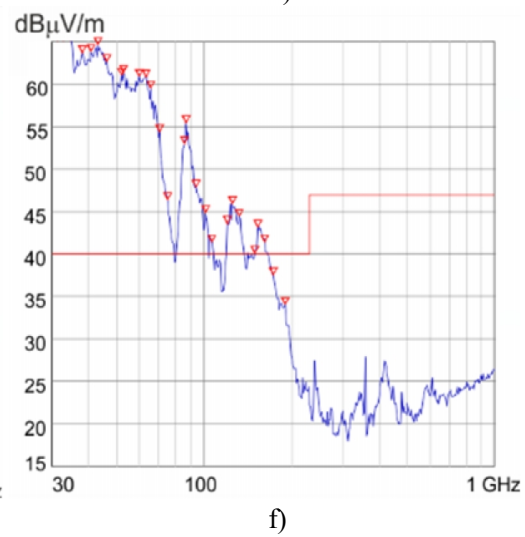




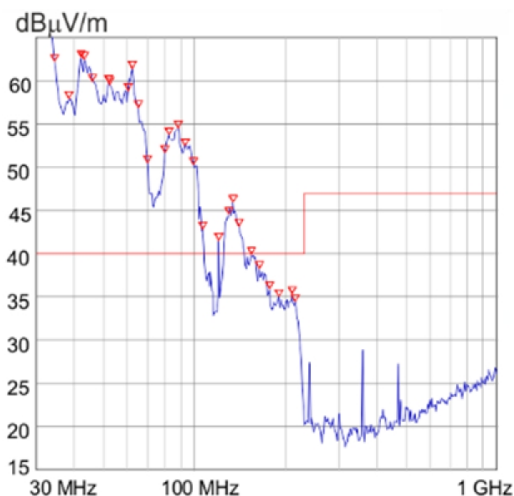

g)

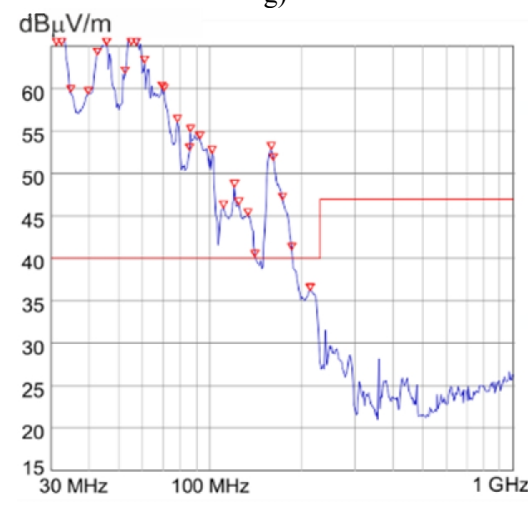

i)

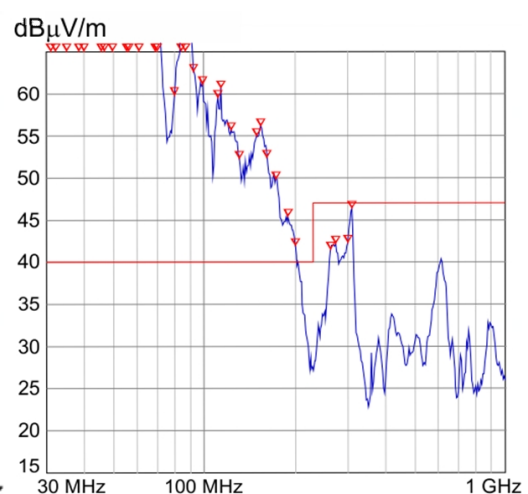

h)

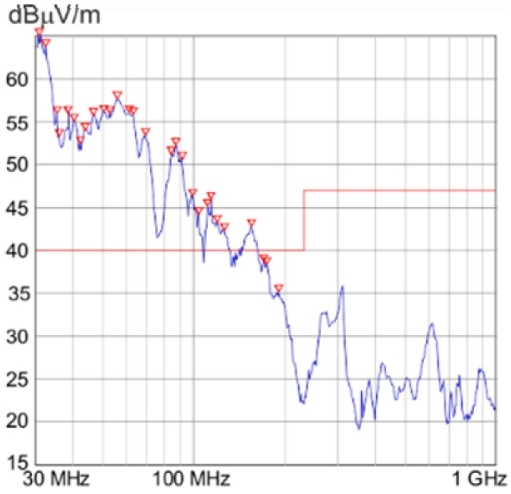

j)

Fig. 5. The results obtained for conducted disturbances (a-e) and radiated emission ( $\mathrm{f}-\mathrm{j}$ ), only the worst cases for each tested Impedance Source Inverters (ISI) are presented. Relative error smaller than $3 \mathrm{~dB}$ : a) ZSI, $R_{L O A D}=47 \Omega, d z=0.40$, VOUTpp $=120 \mathrm{~V}$, b) qZSI, $R_{L O A D}=47 \Omega, d Z=0.40$, VOUTpp $=120 \mathrm{~V}$, c) SLZSI, $R_{L O A D}=47 \Omega, d_{Z}=0.27, V_{\text {OUTp }}=120 \mathrm{~V}$, d) CqZSI, $R_{L O A D}=47 \Omega, d_{Z}=0.27$, VOUTpp $=120 \mathrm{~V}$, e) LCCTqZSI, $R_{L O A D}=47 \Omega, d_{Z}=0.35, V_{O U T p p}=$ $120 \mathrm{~V}$, f) ZSI, $R_{L O A D}=47 \Omega, d_{Z}=0.40$, VOUTpp $=120 \mathrm{~V}$, g) qZSI, $R_{L O A D}=47 \Omega, d_{Z}=0.40$, VOUTpp $\left.=120 \mathrm{~V}, \mathrm{~h}\right)$ SLZSI, $R_{L O A D}=47 \Omega, d_{Z}=0.27, V_{O U T p p}=$ $120 \mathrm{~V}$, i) CqZSI, $R_{L O A D}=47 \Omega, d Z=0.27, V_{\text {OUTPp }}=120 \mathrm{~V}$, j) LCCTqZSI, $R_{L O A D}=47 \Omega, d_{Z}=0.35$, VOUTpp $=120 \mathrm{~V}$.

\section{REFERENCES}

[1] F. Z. Peng, "Z-Source inverter", IEEE Trans. Industry Applications, vol. 39, no. 2, pp. 504-510, 2003. [Online]. Available: http://dx.doi.org/10.1109/TIA.2003.808920

[2] S. Rajakaruna, L. Jayawickrama, "Steady-state analysis and designing impedance network of z-source inverters", IEEE Trans. Industrial Electronics, vol. 57, no. 7, pp. 2483-2491, 2010. [Online]. Available: http://dx.doi.org/10.1109/TIE.2010.2047990

[3] Y. P. Siwakoti, F. Z. Peng, F. Blaabjerg, P. C. Loh, G. E. Town, "Impedance-source networks for electric power conversion part i: a topological review", IEEE Trans. Power Electronics, vol. 30, no. 2, pp. 699-716, 2015. [Online]. Available: http://dx.doi.org/ 10.1109/TPEL.2014.2313746

[4] O. Ellabban, H. Abu-Rub, S. Bayhan, "Z-source matrix converter: an overview", IEEE Trans. Power Electronics, vol. 31, no. 11, pp. 7436-7450, 2016. [Online]. Available: http://dx.doi.org/10.1109 /TPEL.2015.2471799

[5] E. Babaei, E. Shokati Asl, M. Hasan Babayi, S. Laali, "Developed embedded switched-Z-source inverter", IET Power Electronics, vol. 9, no. 9, pp. 1828-1841, 2016. [Online]. Available: http://dx.doi.org/10.1049/iet-pel.2015.0921

[6] M. K. Nguyen, Y. C. Lim, J. H. Choi, Y. O. Choi, "Trans-switched boost inverters", IET Power Electronics, vol. 9, no. 5, pp. 10651073, 2016. [Online]. Available: http://dx.doi.org/10.1049/ietpel.2015.0202

[7] Z. Rymarski, K. Bernacki, "Influence of Z-Source output impedance on dynamic properties of single-phase voltage source inverters for uninterrupted power supply", IET Power Electronics, vol. 7, no. 8, pp. 1978-1988, 2014. [Online]. Available: http://dx.doi.org/ 10.1049/iet-pel.2013.0722

[8] Z. Rymarski, K. Bernacki, "Different approaches to modelling singlephase voltage source inverters for uninterruptible power supply systems", IET Power Electronics, vol. 9, no. 7, pp. 1513-1520, 2016. [Online]. Available: http://dx.doi.org/10.1049/iet-pel.2015.0142

[9] T. Ahmed, S. Mekhilef, "Semi-z-source inverter topology for gridconnected photovoltaic system", IET Power Electronics, vol. 8, no. 1, pp. 63-75, 2015. [Online]. Available: http://dx.doi.org/10.1049/ietpel.2013.0486
[10] O. Husev, C. Roncero-Clemente, E. Romero-Cadaval, D. Vinnikov, T. Jalakas, "Three-level three-phase quasi-Z-source neutral-pointclamped inverter with novel modulation technique for photovoltaic application", Electric Power Systems Research, vol. 130, no. 1, pp. 10-21, 2016. [Online]. Available: http://dx.doi.org/10.1016/ j.epsr.2015.08.018

[11] C. Roncero-Clemente, E. Romero-Cadaval, O. Husev, J. Martins, "New operation strategy for a grid-connected three-phase three-level NPC qZS inverter based on power losses", Elektronika ir Elektrotechnika, vol. 22, no. 3, pp. 60-65, 2016. [Online]. Available: http://dx.doi.org/10.5755/j01.eie.22.3.15316

[12] E. B. Joffe, K. S. Lock, E. Bogatin, Grounds for Grounding: A Circuit-to-System Handbook. New Jersey: John Wiley \& Sons, Inc., 2010. [Online]. Available: http://dx.doi.org/10.1002/978047052932

[13] H. W. Ott, Electromagnetic Compatibility Engineering. New Jersey: John Wiley \& Sons, Inc., 2009. [Online]. Available: http://dx.doi.org/10.1002/9780470508510

[14] K. Bernacki, Z. Rymarski, "Electromagnetic compatibility of voltage source inverters for uninterruptible power supply system depending on the pulse-width modulation scheme", IET Power Electronics, vol. 8, no. 6, pp. 1026-1034, 2015. [Online]. Available: http://dx.doi.org/10.1049/iet-pel.2014.0637

[15] Y. P. Siwakoti, F. Z. Peng, F. Blaabjerg, P. C. Loh, G. E. Town, S. Yang, "Impedance-source networks for electric power conversion part II: review of control and modulation techniques", IEEE Trans. Power Electronics, vol. 30, no. 4, pp. 1887-1906, 2015. [Online]. Available: http://dx.doi.org/10.1109/TPEL.2014.2329859

[16] J. Anderson, F. Z. Peng, "Four quasi-Z-source inverters", in Power Electronics Specialists Conf. (PESC), 2008, pp. 2743-2749. [Online]. Available: http://dx.doi.org/10.1109/PESC.2008.4592360

[17] D. Vinnikov, I. Roasto, R. Strzelecki, M. Adamowicz, "Step-up DC/DC converters with cascaded quasi-Z-source network", IEEE Trans. Industrial electronics, vol. 59, pp. 3727-3736, 2012. [Online]. Available: http://dx.doi.org/10.1109/TIE.2011.2178211

[18] M. Zhu, K. Yu, F. Luo, "Switched inductor Z-source inverter", IEEE Trans. Power Electronics, vol. 25, no. 8, pp. 2150-2158, 2010. [Online]. Available: http://dx.doi.org/10.1109/TPEL.2010.2046676

[19] M. Adamowicz, "LCCT-Z-source inverters", in 10th Int. Conf. on Environment and Electrical Engineering (EEEIC 2011), Rome, 
2011, pp. 1-6. [Online]. Available: http://dx.doi.org/10.1109 /EEEIC.2011.5874799

[20] M. Shen, J. Wang, A. Joseph, F. Z. Peng, L. Tolbert, D. Adams, "Constant boost control of the z-source inverter to minimize current ripple and voltage stress", IEEE Trans. Industry Applications, vol. 42, no. 3, 2006. [Online]. Available: http://dx.doi.org /10.1109/TIA.2006.872927

[21] F. Z. Peng, M. Shen, Z. Qian, "Maximum boost control of the Zsource inverter", IEEE Trans. Power Electronics, vol. 20, no. 4, pp. 833-838, 2005. [Online]. Available: http://dx.doi.org/10.1109/ TPEL.2005.850927

[22] Z. Rymarski, K. Bernacki, L. Dyga, "The influence of the properties of magnetic materials on a voltage source inverter control", in Proc. $23^{\text {rd }}$ IEEE Conf. on Control Applications (CCA), Antibes, France, 2014, pp. 1127-1132. [Online]. Available: http://dx.doi.org/10.1109/ CCA.2014.6981480

[23] K. Detka, K. Gorecki, J. Zarebski, „Modeling single inductor dc - dc converters with thermal phenomena in the inductor taken into account", IEEE Trans. Power Electronics, pp. 1-9, 2017. [Online] Available: http://dx.doi.org/10.1109/TPEL.2016.2628202

[24] K. Gorecki, K. Detka, "Electrothermal model of choking-coils for the analysis of dc-dc converters", Materials Science and Engineering: B, vol. 177, no. 15, pp. 1248-1253, 2012. [Online]. Available: http://dx.doi.org/10.1016/j.mseb.2012.03.033

[25] K. Gorecki, M. Rogalska, J. Zarebski, "Parameter estimation of the electrothermal model of the ferromagnetic core", Microelectronics Reliability, vol. 54, no. 5, pp. 978-984, 2014. [Online]. Available: http://dx.doi.org/10.1016/j.microrel.2014.02.003

[26] R. Kolano, A. Kolano-Burian, M. Polak, J. Szynowski, "Application of rapidly quenched soft magnetic materials in energy-saving electric equipment", IEEE Trans. Magnetics, vol. 50, no. 4, pp. 1-4, 2014 [Online]. Available: http://dx.doi.org/10.1109/TMAG.2013.2283918

[27] Y. Zhu, M. Chen, X. Lee, Y. Tsutomu, "A novel quasi-resonant softswitching Z-source inverter", in IEEE Int. Conf. Power and Energy (PECon 2012), Kota Kinabalu, 2012. [Online]. Available: http://dx.doi.org/10.1109/PECon.2012.6450225

[28] O. Ellabban, H. Abu-Rub, "Z-source inverter: topology improvements review", IEEE Industrial Electronics Magazine, vol. 10, no. 1, pp. 6 24, 2016. [Online]. Available: http://dx.doi.org/10.1109 /MIE.2015.2475475

[29] Z. Rymarski, "Design method of single-phase inverters for UPS systems", International Journal of Electronics, vol. 96, no. 5, pp. 521-535, 2009. [Online]. Available: http://dx.doi.org/10.1080 /00207210802696126 